\title{
HASIL BELAJAR MATEMATIKA SISWA DITINJAU DARI KEMAMPUAN METAKOGNISI DAN PROKRASTINASI AKADEMIK
}

\author{
(STUDENT MATHEMATICS LEARNING OUTCOMES \\ JUDGING FROM METACOGNITION ABILITY \\ AND ACADEMIC PROCRASTINATION)
}

\author{
Shevi Ikhsan ${ }^{1}$, Ibrahim ${ }^{2}$ \\ ${ }^{1,2}$ UIN Sunan Kalijaga Yogyakarta, ibrahim@uin-suka.ac.id
}

\begin{abstract}
Abstrak
Penelitian ini memiliki tujuan untuk mengetahui pengaruh kemampuan metakognisi dan prokrastinasi akademik terhadap hasil belajar matematika siswa. Jenis penelitian ini merupakan penelitian korelasional. Penelitian ini dilaksanakan di salah satu MAN di Bantul pada kelas XI tahun ajaran 2020/2021. Subjek sampel yang digunakan sebanyak 38 siswa. Teknik pengambilan sampel menggunakan simple random sampling. Instrumen yang digunakan berupa skala kemampuan metakognisi dan skala prokrastinasi akademik, serta tes hasil belajar matematika. Tes hasil belajar matematika yang digunakan adalah tes hasil belajar matematika pada penilaian akhir semester (PAS). Teknik analisis data menggunakan analisis regresi ganda didahukui dengan melakukan uji asumsi klasik. Hasil analisis menunjukkan: 1) adanya pengaruh positif secara signifikan kemampuan metakognisi terhadap hasil belajar matematika siswa; 2) adanya pengaruh negatif secara signifikan prokrastinasi akademik terhadap hasil belajar matematika siswa; 3) adanya pengaruh signifikan kemampuan metakognisi dan prokrastinasi akademik secara bersama-sama terhadap hasil belajar matematika siswa. Hasil penelitian ini menyarankan kepada guru untuk menggunakan strategi belajar yang memberikan kesempatan untuk terlatihnya metakognisi siswa, Selain itu, hasil penelitian ini juga menyarankan kepada guru untuk memberikan motivasi belajar pada siswa untuk tidak terjadinya prokrastinasi akademik karena berdampak negatif terhadap hasil belajar matematika siswa.
\end{abstract}

Kata kunci: Hasil Belajar, Metakognisi, Prokrastinasi Akademik

\begin{abstract}
This study aims to determine the effect of metacognition abilities and academic procrastination on students' mathematics learning outcomes. This research was conducted in one of the MAN in Bantul in XI class for the 2020/2021 academic year. The sample subjects were 38 students. The sampling technique was simple random sampling. The instrument is a scale of metacognition ability and academic procrastination scale, as well as a test of mathematics learning outcomes. The mathematics learning outcomes test used is the mathematics learning outcome test at the end of the semester assessment. The data analysis technique used multiple regression analysis and classical assumption test. The results of the analysis are: 1) there is a significant positive effect on the ability of metacognition on student mathematics learning outcomes; 2) there is a significant negative effect of academic procrastination on students' mathematics learning outcomes; 3)
\end{abstract}


there is a significant effect of academic metacognition and procrastination abilities together on student mathematics learning outcomes. The results of this study suggest that teachers use learning strategies that provide opportunities for student metacognition to be trained. In addition, the results of this study also suggest teachers motivate students to avoid academic procrastination because it harms student mathematics learning outcomes.

Keywords: Learning Outcomes, Metacognition, Academic Procrastination

\section{PENDAHULUAN}

Indonesia sebagai bagian dari negara di dunia, turut serta membangun peradaban dengan modalitas pendidikan selaku usaha untuk mengembangkan sumber daya manusia yang bermutu. Ihwal ini termuat pada UUD 1945 Ayat 1 serta 2 Pasal 31 yang menerangkan bahwa segenap warga negara memiliki hak untuk mengakses pendidikan dan segenap warga negara wajib mengakses pendidikan dasar di sekolah serta pemerintah wajib menanggungnya. Selain itu, pada UU RI pasal 37 tahun 2003 No. 20 perihal kurikulum pendidikan dasar dan menengah wajib memasukkan salah satunya mata pelajaran matematika. Matematika pada jenjang sekolah merupakan materi matematika yang dipilih untuk diajarkan di sekolah sesuai dengan jenjang kelas dan sekolah, yang selanjutnya dikatakan sebagai matematika sekolah (Chairani, Zahra, 2016: 2).

Matematika mempunyai peran yang berarti untuk meningkatkan keahlian berpikir logis, sistematis, serta kritis (Sulistiani dan Masrukan, 2016: 605). Selain itu, mempelajari matematika bisa membantu untuk menyelesaikan permasalahan kehidupan sehari-hari (Siagian, 2016: 123). Di zaman persaingan yang makin kompetitif, menguasai pelajaran matematika diperlukan untuk melatih nalar dan mengambil setiap keputusan (Siagian, 2016: 60).

Proses belajar matematika tentu jamak dijumpai dengan masalah-masalah. Salah satu sebab siswa mengalami kesukaran dalam belajar matematika karena karakteristik matematika yang cenderung abstrak serta sistematis yang membuat daya minat siswa berkurang untuk mempelajarinya (Harahap dan Syarifah, 2015: 21). Selain itu, siswa menjadi terkendala dan mengalami kesulitan memahami matematika lantaran berpandangan bahwa materi matematika itu rumit dan sukar (Yusmin, 2017: 20). Pandangan tersebut merupakan pandangan negatif siswa terhadap matematika yang dapat menghambat mencapai target belajar. Anggapan yang didapat serta diterapkan akan berdampak terhadap perilaku siswa selama melakukan aktivitasnya, lantaran penilaian seseorang tentang suatu objek juga akan berdampak pada kesuksesan dalam mencapai apa yang menjadi tujuannya (Syamarro, 2015: 2). Gani (2015: 342) memaparkan bahwa persepsi siswa dalam materi matematika ditemukan adanya pengaruh terhadap hasil belajar matematika secara signifikan.

Tolak ukur kesuksesan pembelajaran disebut dengan hasil belajar (Faelasofi, 2017: 156). Hasil belajar yang sudah diketahui memberikan informasi tentang keoptimalan capaian belajar siswa tersebut. Usaha mendapatkan hasil belajar yang optimal sangat berguna untuk perencanaan meningkatkan sumber daya manusia yang bermutu (Ibrahim, 2019: 39). Umumnya pada hasil belajar matematika ada faktor-faktor yang mempengaruhinya, yaitu faktor yang muncul dari dalam diri sendiri (faktor internal) serta faktor yang muncul dari luar (faktor 
eksternal). Faktor internal mencakup motivasi, metakognisi, intelegensi, kecemasan, prokrastinasi, kebiasaan, dan lainnya. Sedangkan faktor eksternal mencakup pada kalangan keluarga, sekolah, masyarakat, kondisi sosial dan ekonomi, dan lainnya. (Fajriani dan Nurdahniar, 2016: 286). Faktor-faktor tersebut bisa mendukung atau menghambat kesuksesan belajar siswa sendiri (Agustina dan Noor, 2016: 193). Dengan demikian, hasil belajar matematika sudah semestinya diketahui secara detil termasuk faktor-faktor yang mempengaruhinya, baik faktor internal maupun eksternal. Informasi tersebut sangat bermanfaat untuk merencanakan dan mendesain upaya-upaya peningkatan hasil belajar matematika tersebut.

Faktor-faktor yang menghambat kesuksesan siswa akan mengakibatkan hasil belajar matematika rendah. Data tahun 2018 yang dikeluarkan oleh Programme for International Student Assessment (PISA) untuk perhitungan global siswa yang berumur 15 tahun memperlihatkan bahwa skor yang diperoleh mendapatkan rata-rata skor pada mata pelajaran matematika siswa di Indonesia yaitu sebesar 379. Hal ini menggambarkan bahwa siswa di Indonesia memiliki skor di bawah rata-rata dari 79 negara yang berpartisipasi pada ajang tersebut, yakni 489 untuk kategori kemampuan matematika siswa. Hal ini mengalami penurunan dari data PISA tahun 2015. Data lain yang dilansir oleh United Nations Educational, Scientific and Cultural Organization (UNESCO), bahwa pada tahun 2018 siswa sekolah menengah di Indonesia mempunyai peringkat 34 dari 38 negara pada kategori hasil belajar matematika (Puspendik, 2019; 35). Laporan dari Asesmen Kompetensi Siswa Indonesia (AKSI) pada siswa Sekolah Menengah tahun 2019 (Puspendik, 2020: 2) menunjukkan bahwa kompetensi matematika siswa di Daerah Istimewa Yogyakarta sebesar 54,51\% dengan keterangan kurang, 39,59\% dengan keterangan cukup, dan 5,9\% dengan keterangan baik. Hasil ini mengungkapkan bahwa hasil belajar matematika siswa masih termasuk rendah, sehingga merupakan hal penting dan mendesak untuk mengkaji dan menindaklanjuti dalam mencari cara agar hasil belajar matematika siswa dapat meningkat.

Guna menaikkan hasil belajar matematika siswa, diperlukan pengoptimalan yang baik terhadap faktor-faktor yang mempengaruhinya. Clark \& Angert (Hasibuan, 2018: 14) melaporkan bahwa kemampuan siswa memiliki pengaruh sebesar $70 \%$ serta lingkungan memiliki pengaruh sebesar $30 \%$ terhadap hasil belajar matematika siswa. Hal ini menggambarkan bahwa faktor internal berpengaruh lebih besar dibandingkan dengan faktor eksternal. Salah dua faktor internal tersebut adalah kemampuan metakognisi dan prokrastinasi akademik.

Kemampuan metakognisi ialah ihwal yang bermanfaat dan penting untuk siswa dalam pembelajaran. Berdasarkan penelitian Supriatna dan Alawiyah (2019: 478) yang menyatakan bahwa kemampuan metakognisi merupakan aspek yang sangat esensial bagi kesuksesan individu dalam proses belajar mereka. Selain itu, revisi dalam dimensi pengetahuan menurut Taksonomi Bloom yang memuat: factual knowledge, conceptual knowledge, procedural knowledge kemudian diimbuhkan dengan kategori ke empat, yaitu metacognition knowledge. Demikian juga dengan konsep kurikulum 2013 pada ruang lingkup standar kompetensi lulusan (SKL) pada jenjang SMA dan Perguruan Tinggi yang telah memberikan ilustrasi pengembangan metakognisi di samping kemampuan faktual, konseptual, dan prosedural (Chairani, 2016: 10). Atas dasar tersebut, aspek-aspek yang 
berhubungan dengan kemampuan metakognisi siswa perlu dikaji lebih dalam, sehingga standar kompetensi lulusan pada jenjang sekolah menengah dapat tercapai.

Faktor internal lainnya yang mempengaruhi hasil belajar adalah prokrastinasi akademik. Prokrastinasi akademik ialah bentuk perilaku penundaan untuk memulai mengerjakan atau menyelesaikan tugas-tugas akademik (Muyana, 2018: 45). Perilaku demikian lazim terjadi pada siswa dan menjadi momok tersendiri dalam setiap menghadapi tugas-tugas akademiknya.

Dewasa ini, perkembangan teknologi semakin berkembang pesat. Perkembangannya mempunyai efek yang positif dan negatif pada kehidupan manusia. Efek negatif ini artinya bahwa siswa memiliki kecenderungan yang tinggi untuk melakukan prokrastinasi akademik (Munawaroh, dkk, 2017: 26). Hal tersebut ditandai dengan kebiasaan siswa yang banyak meluangkan waktu dengan mengakses jejaring sosial, bermain game online, dan menonton televisi. Ferrari, dkk (Munawaroh, dkk: 2017: 27) menyatakan bahwa siswa memiliki masalah dengan perilaku prokrastinasi akademik sebesar 25\% hingga 75\%. Selain itu, penelitian oleh Steel (Ilyas dan Suryadi, 2017: 27) memaparkan bahwa 80\%-90\% siswa terseret beberapa macam perilaku menunda-nunda serta hampir $50 \%$ melakukan penundaan secara konsisten sehingga menyebabkan adanya masalahmasalah dengan tugas.

Perilaku prokrastinasi sangat dekat pada kegagalan sehingga siswa perlu menghindari karena bisa menjadi kendala siswa untuk memperoleh hasil belajar yang diharapkan. Hal ini diperkuat oleh Zuraidah, dkk (2020: 7) yang menyatakan bahwa prokrastinasi akademik memiliki pengaruh pada hasil belajar matematika siswa. Dengan demikian, pelaku prokrastinasi kemungkinan besar bisa kegagalan lantaran pengerjaan tugas belum tuntas sampai batas waktu yang ditentukan, meskipun tugas tersebut tuntas maka hasilnya cenderung tidak akan optimal (Nitami, dkk, 2015: 2).

Pemilihan ini beralasan untuk mengkombinasikan metakognisi dan prokrastinasi akademik sebagai topik penelitian karena beberapa alasan, yang pertama yaitu dua variabel tersebut bagian dari faktor internal yang dapat mempengaruhi hasil belajar matematika. Kedua, jarangnya penelitian yang mengkombinasikan dua variabel tersebut padahal sangat penting untuk dilakukan. Mengingat urgensi dari kemampuan metakognisi yang dimuat dalam standar kompetensi lulusan (SKL) pada kurikulum 2013 yang bersamaan dengan berkembang pesatnya teknologi modern yang mengakibatkan semakin banyaknya peluang siswa untuk melakukan prokrastinasi akademik, maka kemampuan metakognisi dan prokrastinasi akademik penting untuk diteliti lebih lanjut bagaimana pengaruhnya terhadap hasil belajar matematika siswa.

Berdasarkan pemaparan di atas, maka pengkajian masalah penelitian ini yaitu: (1) apakah ada pengaruh positif dan signifikan kemampuan metakognisi terhadap hasil belajar matematika siswa? (2) apakah ada pengaruh negatif dan signifikan prokrastinasi akademik terhadap hasil belajar matematika siswa? (3) apakah ada pengaruh yang signifikan antara kemampuan metakognisi dan prokrastinasi akademik secara bersama-sama terhadap hasil belajar matematika siswa? 


\section{KAJIAN TEORI}

\section{A. Hasil Belajar Matematika}

Hasil belajar dapat dijelaskan dengan memahami dua kata yang membentuknya, yaitu hasil dan belajar (Harianti, 2018: 18). Hasil menunjukkan pada perolehan akibat dilakukannya suatu aktivitas atau proses yang menyebabkan berubahnya input secara fungsional, sedangkan belajar merupakan aktivitas mental atau psikis yang berlangsung dalam interaksi aktif dengan lingkungan yang menghasilkan perubahan-perubahan dalam pengetahuan, keterampilan, dan sikap. Perubahan itu diperoleh melalui usaha (bukan karena kematangan), menetap dalam waktu yang relatif lama dan merupakan hasil dari pengalaman (Purwanto, 2009: 39).

Purwanto (2009:46) mengatakan bahwa hasil belajar merupakan proses belajar yang menyebabkan perubahan pada perilaku. Seseorang mampu memahami materi yang diberikan dalam pembelajaran yang menyebabkan perubahan tersebut. Sudjana (2013: 2) menyatakan bahwa hasil belajar adalah hasil yang didapat seseorang sesudah melakukan pengalaman belajar. Perubahan hasil belajar terjadi pada ranah kognitif, afektif, atau psikomotorik. Nasution (Jumalia, 2018: 8) mengatakan bahwa hasil belajar merupakan suatu perubahan pada individu baik sedang belajar, serta tidak hanya perubahan yang berkaitan dengan pengetahuan, melainkan juga melatih keterampilan serta penghargaan pada pribadi sendiri dalam belajar. Definisi hasil belajar menurut beberapa ahli tersebut menunjukkan bahwa adanya perubahan perilaku setelah mengikuti proses belajar merupakan indikasi dari hasil belajar. Berdasarkan uraian di atas, maka dalam penelitian ini menyimpulkan bahwa hasil belajar matematika adalah capaian siswa dalam kurun waktu tertentu ataupun hasil perubahan tingkah laku pada kurun waktu tertentu dalam belajar matematika.

\section{B. Kemampuan Metakognisi}

Istilah metakognisi menurut Shetty (Paristu: 2020: 23) terdiri dari term meta serta kognisi. Meta berarti setelah atau di atasnya, sedangkan kognisi berarti mengetahui. Jadi, secara istilah metakognisi bisa dimaknakan dengan kognisi tentang kognisi, atau berpikir tentang berpikir. Pengertian tersebut dipaparkan oleh banyak ahli. Awal mula istilah metakognisi dipaparkan pada tahun 1970-an oleh Flavell yang berasal dari Universitas Stanford, yang kemudian jamak membuat pergesekan definisi (Apriani \& Ibrahim, 2021: 48).

Wellman (Mulbar, 2008: 4) mengatakan bahwa metakognisi merupakan bentuk dari kognisi, atau suatu proses berpikir ke tingkat tinggi yang menyangkut kontrol pada kegiatan kognitif. Selain itu, metakognisi menyangkut pengetahuan serta kesadaran tentang kegiatan kognitif diri sendiri atau yang bertautan dengan kegiatan kognitif. Oleh karena itu, Livingson (Mulbar, 2008) mengatakan bahwa kegiatan kognitif serupa melakukan perencanaan, pemantauan, serta mengevaluasi suatu pemecahan masalah tertentu disebut metakognisi yang alamiah.

Flavel (Chairani, 2016: 34) mengatakan bahwa metakognisi ialah pengetahuan tentang kognisi, atau apa saja yang berkaitan dengan proses berpikir seperti belajar perihal keterkaitan antar sifat-sifat dari suatu informasi. Sedangkan Moore (2004) mengatakan bahwa metakognisi merujuk kepada pemahaman tentang pengetahuannya sendiri, apabila pemahamannya cenderung dalam tentang pengetahuannya tersebut maka akan memperlihatkan penggunaannya yang efektif. 
Berdasarkan pendapat para ahli di atas, bisa menarik konklusi bahwa kemampuan metakognisi adalah pengetahuan dan kesadaran tentang aktivitas atau kegiatan kognitif dalam proses belajar.

\section{Prokrastinasi Akademik}

Solomon dan Rothblum (Setiyowati, 2016: 11) memaparkan bahwa prokrastinasi merupakan bentuk yang mengarah pada menunda-nunda untuk melakukan permulaan mengerjakan tugas dengan menyeluruh dengan melaksanakan kegiatan lain yang kurang relevan yang menyebabkan pekerjaan utama terhambat serta untuk menuntaskannya tidak pada waktu yang tepat. Prokrastinasi bisa pula diartikan sebagai penundaan atau penghindaran tugas dikarenakan perasaan tidak suka atau merasa ketakutan akan gagal dalam menyelesaikan tugas.

Knaus (Wati, 2012: 12) mengemukakan bahwa proses menunda yang kemudian jadi respon tetap ataupun kebiasaan bisa disebut dengan perilaku prokrastinasi, dengan pengertian bahwa prokrastinasi dilihat lebih dari sekadar kecenderungan tetapi sesuatu respon tetap untuk menjaga pekerjaan yang tidak disenangi serta dilihat tidak dituntaskan dengan baik. Selain itu, menunda-nunda dapat disebut prokrastinasi jika perilaku tersebut telah menjadi kebiasaan yang tetap yang ingin dilaksanakan oleh siswa saat mengerjakan tugas serta menundanunda untuk menyelesaikannya dengan adanya keyakinan yang tidak masuk akal.

Ferrari, dkk (Ghufron dan Risnawati, 2012: 153) memaparkan bahwa prokrastinasi merupakan suatu bentuk keterlambatan yang disengaja ketika menyelesaikan tugas sekalipun telah mengetahui dengan adanya akibat yang buruk. Lebih lanjut Ferrari, dkk (Ghufron dan Risnawati, 2012: 154) memaparkan bahwa prokrastinasi bisa dipandang dari sudut pandang yang berbeda, yaitu pertama sebagai perilaku menunda-nunda, tanpa meninjau tujuan dan argumentasi menunda-nunda tersebut dilakukan, kedua sebagai kebiasaan tetap yang cenderung kepada sebuah perilaku atau respon tetap yang diikuti dengan keyakinan yang tidak masuk akal, ketiga sebagai perilaku kepribadian, yaitu tidak sekadar dalam bentuk perilaku melainkan trait menyangkut dengan struktur mental.

Prokrastinasi berlaku pada banyak segi dalam kehidupan seperti dalam akademik (Masgarini, 2018). Menurut Ferrari, dkk (Ghaida, 2019: 8) yang memaparkan bahwa prokrastinasi akademik ialah masalah pengaturan diri ketika hendak memulai maupun menyelesaikan suatu pekerjaan atau tugas- tugas akademik. Lebih lanjut dianggap mengarah kepada sifat pribadi yang biasa menghadapi pekerjaan dengan batas waktu tertentu (Suherni, 2016). Berdasarkan pendapat di atas, dapat disimpulkan bahwa prokrastinasi akademik adalah perilaku menunda yang dilakukan secara sengaja dan berulang-ulang dalam menyelesaikan tugas-tugas akademik dengan melakukan aktivitas lain yang tidak relevan pada pengerjaan tugas yang utama.

\section{METODE}

Penelitian ini merupakan jenis penelitian korelasional. Hal ini karena penelitian ini berkaitan dengan pengumpulan data untuk menentukan adanya hubungan antar dua atau lebih variabel (Sukardi, 2011: 166). Selain itu menentukan hubungan dua variabel, penelitian korelasional yang dilakukan ini 
juga meninjau tentang hubungan sebab akibat dari variabel-variabel yang berkaitan yang dilibatkan dalam penelitian.

Penelitian dilaksanakan di salah satu MAN di Bantul pada siswa kelas XI semster genap tahun ajaran 2020/2021. Bantul merupakan salah satu kabupaten yang berada di Daerah Istimewa Yogyakarta. Adapun instrumen penelitiannya yaitu skala kemampuan metakognisi dan skala prokrastinasi akademik dengan masing-masing memuat 24 pernyataan, serta hasil penilaian akhir semester (PAS).

Populasi penelitian ini ialah siswa kelas XI yang berukuran 126. Penelitian mengambil beberapa siswa untuk dijadikan subjek sampel. Jika jumlah siswa kurang dari 100, maka sampel bisa mengambil secara menyeluruh agar penelitian yang dilakukan disebut penelitian populasi, sedangkan jika jumlah siswa lebih dari 100 maka proses memilih sampel $10 \%-15 \%$ atau $20 \%-25 \%$ atau lebih (Arikunto, 2010: 112). Sampel pada penelitian ini ialah 30\% dari populasi yaitu sebanyak 38 siswa. Adapun teknik pengambilan sampelnya yaitu simple random sampling. Teknik tersebut dapat diterapkan dengan random dengan tidak melihat tingkatan data pada populasi. Dengan demikian, teknik tersebut bisa dilakukan pada populasi yang dipandang homogen (Sugiyono, 2015: 63).

Instrumen dalam penelitian ini menggunakan skala kemampuan metakognisi $(X 1)$ serta skala prokrastinasi akademik (X2). Skala tersebut diujikan kepada siswa untuk mengetahui apakah ada atau tidakpengaruh kemampuan metakognisi dan prokrastinasi akademik terhadap hasil belajar matematika siswa. Pembuatan skala dalam penelitian ini mengacu pada komponen yang diperjelas dengan kisi-kisi untuk menyatakan setiap butir pernyataan yang terdapat pada skala. Instrumen skala kemampuan metakognisi dan prokrastinasi akademik terdiri dari 24 butir pernyataan dengan rerata CVR adalah 1 . Hal ini berarti bahwa skala kemampuan metakognisi dan prokrastinasi akademik dapat dinyatakan valid. Sementara itu, hasil ujicoba menunjukkan bahwa skala kemampuan metakognisi memiliki koefisien reliablitas sebesar 0,749 dan skala prokrastinasi memiliki koefisien reliablitas sebesar 0,849. Hal ini artinya bahwa kedua skala tersebut memiliki reliablitas yang berkategori tinggi.

Adapun hasil belajar siswa dalam penelitian ini menggunakan hasil penilaian akhir semester (PAS). Nilai PAS siswa didapatkan dari dokumen guru matematika kelas XI sekolah yang menjadi tempat penelitian. Penggunaan data PAS ini dengan asumsi bahwa instrumen yang digunakan pada PAS telah diverifikasi dalam forum guru matematika di sekolah tersebut sehingga memenuhi standar kualitas alat ukur hasil belajar matematika di sekolah.

\section{HASIL DAN PEMBAHASAN}

Berikut hasil analisis deskriptif seluruh variabel bebas dan terikat pada penelitian yang diperoleh di lapangan. 
Tabel 1. Data Statistik Variabel Penelitian

\begin{tabular}{cccc}
\hline $\begin{array}{c}\text { Parameter } \\
\text { Statistik } \\
\text { Deskriptif }\end{array}$ & $\begin{array}{c}\text { Hasil Belajar } \\
\text { Matematika } \\
\text { Siswa }\end{array}$ & $\begin{array}{c}\text { Kemampuan } \\
\text { Metakognisi }\end{array}$ & $\begin{array}{c}\text { Prokrastinasi } \\
\text { Akademik }\end{array}$ \\
\hline Minimum & 25 & 48,98 & 45,36 \\
Maksimum & 80 & 84,37 & 95,31 \\
Mean & 50,92 & 70,08 & 71,06 \\
Standar Deviasi & 14,97 & 8,58 & 11,02 \\
\hline
\end{tabular}

Tabel 1 di atas memberikan informasi berupa rata-rata skor skala kemampuan metakognisi dan prokrastinasi akademik. Ada perbedaan rata-rata skor kemampuan metakognisi dan prokrastinasi akademik sebesar 0,98. Namun, penelitian ini tidak akan membandingkan skor antar variabel karena fokus penelitian hanya ingin mengetahui adanya pengaruh antar variabel. Oleh karena itu, penelitian ini hanya mendeskripsikan data yang telah di dapat di lapangan. Tabel $1 \mathrm{di}$ atas juga menunjukkan terkait dengan standar deviasi skor kemampuan metakognisi lebih rendah dari skor prokrastinasi akademik. Hal ini menunjukkan bahwa sebagian besar angka mendekati rata-rata, artinya sebaran skor kemampuan metakognisi dalam sampel yang telah dipilih relatif homogen dan mengumpul di sekitar rata-ratanya, sedangkan standar deviasi prokrastinasi akademik lebih tinggi dari standar deviasi kemampuan metakognisi yang berarti bahwa sebagian besar angka menjauhi rata-ratanya, artinya sebaran skor prokrastinasi akademik dalam sampel yang dipilih lebih luas dan tidak mengumpul pada rata-ratanya.

\section{Uji Asumsi Klasik}

Uji asumsi klasik yang digunakan pada penelitian ini adalah uji normalitas, uji multikolinieritas dan uji heteroskedastisitas. Uji-uji tersebut dibantu dengan menggunakan software statistic. Adapun nilai probalitas yang digunakan sebagai batas pengambilan keputusan adalah 0,05 .

Uji normalitas dilakukan untuk mengetahui kenormalan distribusi data variabel bebas dan variabel terikat. Pengujian normalitas dengan metode Kolmogorov-Smirnov disajikan pada tabel berikut. Hasil pengujian normalitas menunjukkan bahwa ketiga data variabel penelitian berasal dari populasi berdistribusi normal dengan ditunjukkan nilai sig. pada uji Kolmogorov-Smirnov yaitu sebesar 0,200 >0,005.

Uji multikolinieritas dilakukan untuk menguji apakah antar variabel bebas ditemukan adanya korelasi yang tinggi. Hasil pengujian multikolinieritas menggunakan nilai tolerance dan nilai VIF menunjukkan bahwa ketiga data variabel penelitian memiliki nilai tolerance $>0,100$ dan nilai VIF $<10,00$. Ini artinya bahwa data terbebas dari multikolinieritas.

Uji heteroskedastisitas digunakan untuk menguji residual antar variabel bebas apakah terjadi ketidaksamaan variansi dari residual. Hasil pengujian heteroskedastisitas menggunakan metode uji Glejser, menunjukkan bahwa ketiga data variabel penelitian memiliki nilai sig. $>0,05$. Ini artinya bahwa data terbebas dari heteroskedastisitas.

\section{Uji Parsial (Uji t)}

Uji t dilakukan untuk melihat pengaruh variabel bebas secara parsial yang 
dapat menerangkan variabel terikat. Adapun hasil uji t disajikan pada tabel berikut.

Tabel 2. Hasil Uji t

\begin{tabular}{cccc}
\hline Model & Koefisien Regresi & t & Sig. \\
\hline (Constant $)$ & & 1.510 & 0,140 \\
Kemampuan Metakognisi & 0,577 & 2.081 & 0.045 \\
Prokrastinasi Akademik & $-0,505$ & $-2,339$ & 0.025 \\
\hline
\end{tabular}

Tabel 2 di atas menunjukkan bahwa nilai sig kedua variabel $<0,05$. Perbandingan nilai $t_{\text {hitung }}$ dengan nilai $t_{\text {tabel }}$. Nilai $t_{\text {hitung }}$ diperoleh dengan menggunakan presentase titik distribusi, karena dalam analisis regresi menggunakan probabilitas dua sisi maka dibutuhkan nilai degree of freedom (df). Didapat nilai $\mathrm{df}=38$, dengan melihat titik presentase distribusi t maka diperoleh nilai $t_{\text {tabel }}$ sebesar 1,686 . Perolehan nilai $t_{\text {hitung }}$ kemampuan metakognisi dan prokrastinasi akademik yaitu nilai $t_{\text {hitung }}$ kedua variabel bebas $>1,686$. Jadi, hasil perhitungan ini menyimpulkan bahwa kemampuan metakognisi berpengaruh positif secara signifikan terhadap hasil belajar matematika siswa dan prokrastinasi akademik berpengaruh negatif secara signifikan terhadap hasil belajar matematika siswa.

\section{Uji Simultan (Uji F)}

Uji $\mathrm{F}$ digunakan untuk menguji apakah variabel bebas secara simultan mempunyai pengaruh terhadap variabel terikat. Adapun hasil uji $\mathrm{F}$ menggunakan ANNOVA hasilnya disajikan pada tabel berikut.

Tabel 3. Hasil Uji F

\begin{tabular}{ccc}
\hline Model & F & Sig \\
\hline Regresi & 10.811 & 0.000 \\
\hline
\end{tabular}

Tabel 3 di atas menunjukkan bahwa memberikan informasi mengenai besarnya nilai $F_{\text {hitung }}$ dan sig, untuk mencapai dasar pengambilan keputusan langkah pertama yang harus dilakukan yaitu membandingkan nilai $F_{\text {hitung }}$ dengan nilai $F_{\text {tabel }}$. Nilai $F_{\text {tabel }}$ diperoleh dengan menggunakan presentase titik distribusi, karena dalam analisis regresi menggunakan probabilitas dua sisi maka dibutuhkan nilai derajat bebas atau degree of freedom $\left(\mathrm{df}_{(\mathrm{n} 1)}\right)$ dan $\left(\mathrm{df}_{(\mathrm{n} 2)}\right)$. Nilai diperoleh adalah $\mathrm{df}_{(\mathrm{n} 1)}=2$ dan $\mathrm{df}_{(\mathrm{n} 2)}=38$. Berdasarkan pertimbangan titik presentase distribusi F maka diperoleh nilai $F_{\text {tabel }}$ sebesar 3,26.

Uji $\mathrm{F}$ berkaitan pada uji sebelumnya yaitu uji $\mathrm{t}$, karena pada uji $\mathrm{t}$ kemampuan metakognisi dan prokrastinasi akademik berpengaruh pada hasil belajar matematika siswa, maka dapat dipastikan bahwa pada uji $\mathrm{F}$ kemampuan metakognisi dan prokrastinasi akademik akan berpengaruh secara bersama-sama. Hasil tersebut sesuai dengan kriteria dasar pengambilan keputusan yaitu nilai sig. $<0,05$ dan $F_{\text {hitung }}>F_{\text {tabel }}$, sehingga dapat disimpulkan terdapat pengaruh yang signifikan secara bersama-sama antara kemampuan metakognisi dan prokrastinasi akademik terhadap hasil belajar

Koefisien determinasi bertujuan untuk menjelaskan variasi pengaruh variabel kemampuan metakognisi dan prokrastinasi akademik terhadap hasil 
belajar matematika siswa. koefisien determinasi diperoleh dari hasil perkalian nilai Adjusted $R$ Square dengan $100 \%$. Adapun hasil uji koefisien determinasi disajikan pada tabel berikut.

Tabel 4. Koefisien Determinasi

\begin{tabular}{ccccc}
\hline Model & $\mathbf{R}$ & $\mathbf{R}$ Square & $\begin{array}{c}\text { Adjusted } \mathbf{R} \\
\text { Square }\end{array}$ & $\begin{array}{c}\text { Std. Error of } \\
\text { the estimate }\end{array}$ \\
\hline $\mathbf{1}$ & 0,618 & 0,382 & 0,347 & 12.10195 \\
\hline
\end{tabular}

Tabel 4 memberikan informasi bahwa nilai Adjusted $R$ Square sebesar 0,347 menunjukkan bahwa proporsi pengaruh kemampuan metakognisi dan prokrastinasi akademik pada variabel hasil belajar matematika siswa sebesar $34,7 \%$. Artinya, kemampuan metakognisi dan prokrastinasi akademik memiliki proporsi pengaruh terhadap hasil belajar matematika siswa sebesar 34,7\% sedangkan sisanya 65,3\% dipengaruhi oleh variabel lain yang tidak diteliti.

Syarat-syarat uji asumsi klasik dan uji kelayakan telah terpenuhi, maka pada tahap terakhir adalah menginterpretasikan model yang digunakan. Interpretasi model dapat dibuat dengan melihat nilai koefisien beta pada tabel berikut.

Tabel 5 Interpretasi Model

\begin{tabular}{|c|c|c|c|c|}
\hline & \multirow[t]{2}{*}{ Model } & \multicolumn{2}{|c|}{ Unstandardized Coefficients } & \multirow{2}{*}{$\frac{\text { Standardized Coefficients }}{\text { Beta }}$} \\
\hline \multirow{4}{*}{1} & & $\mathrm{~B}$ & Std. Error & \\
\hline & (Constant) & 46,354 & 30,692 & \\
\hline & $\begin{array}{l}\text { Kemampuan } \\
\text { Metakognisi }\end{array}$ & 0,577 & 0,277 & 0,331 \\
\hline & $\begin{array}{l}\text { Prokrastinasi } \\
\text { Akademik }\end{array}$ & $-0,505$ & 0,216 & $-0,372$ \\
\hline
\end{tabular}

Berdasarkan Tabel 5 di atas diperoleh interpretasi model sebagai berikut:

$$
\begin{gathered}
Y=46,354+0,577 X_{1}-0,505 X_{2} \\
\quad \text { atau } \\
Y=46,354+0,577 K M-0,505 P A
\end{gathered}
$$

Koefisien kemampuan metakognisi (KM) bernilai positif yang artinya apabila siswa memiliki kemampuan metakognisi yang tinggi maka hasil belajar matematika siswa yang didapat juga tinggi. Begitupun sebaliknya, apabila siswa yang memiliki kemampuan metakognisi rendah maka hasil belajar matematika siswa yang didapat cenderung rendah. Kemudian pada koefisien prokrastinasi akademik (PA) bernilai negatif, artinya jika siswa yang melakukan prokrastinasi akademik tinggi maka hasil belajar matematika siswa yang didapat cenderung rendah. Sebaliknya, jika siswa yang melakukan prokrastinasi akademik rendah maka hasil belajar matematika siswa yang didapat cenderung tinggi.

Pengujian hipotesis pertama pada penelitian ini, yaitu menguji mengenai pengaruh kemampuan metakognisi terhadap hasil belajar matematika siswa. Hasil analisis mengenai pengaruh kemampuan metakognisi terhadap hasil belajar matematika siswa menunjukkan bahwa adanya pengaruh positif dan signifikan antara kemampuan metakognisi terhadap hasil belajar matematika siswa. Hal ini sesuai dengan dasar pengambilan keputusan, bahwa jika nilai $t_{\text {hitung }}>t_{\text {tabel }}$ dan 
nilai sig. $<0,05$ serta koefisien regresi bernilai positif maka terdapat pengaruh positif dan signifikan antara kemampuan metakognisi terhadap hasil belajar matematika siswa.

Hasil pengolahan data menggunakan software statistik menunjukkan bahwa nilai $t_{\text {hitung }}$ lebih besar dari $t_{\text {tabel }}$ atau dapat dituliskan dengan $t_{\text {hitung }}(2,081)>$ $t_{\text {tabel }}(1,686)$. Perolehan nilai sig. pada variabel kemampuan metakognisi terhadap hasil belajar matematika lebih kecil dari 0,05 atau dapat dituliskan sig. $(0,045)<$ 0,05. Sehingga dapat disimpulkan bahwa penelitian yang dilakukan di kelas XI di salah satu MAN di Bantul ini memenuhi salah satu hipotesis (hipotesis pertama) yang diajukan, yaitu bahwa kemampuan metakognisi berpengaruh positif dan signifikan terhadap hasil belajar matematika siswa.

Penelitian ini juga melakukan perhitungan interpretasi model dengan melihat pengaruh kemampuan metakognisi $\left(X_{1}\right)$ terhadap hasil belajar matematika siswa $(Y)$. Hasil perhitungan interpretasi model didapatkan koefisien regresi sebesar 0,577. Dilihat dari koefisien regresi kemampuan metakognisi yang diperoleh tersebut terlihat bahwa koefisien regresi bernilai positif, artinya variabel kemampuan metakognisi berpengaruh positif terhadap hasil belajar matematika siswa. Hal ini dapat diartikan bahwa dengan bertambahnya kemampuan metakognisi sebesar 0,577 setiap satuan dapat meningkatkan hasil belajar matematika siswa sebesar 0,557 dengan menganggap bahwa variabel lain tetap.

Hasil penelitian ini sesuai dengan yang dilakukan oleh Suardi (2013) dan Nurmalasari, dkk (2015) yang menunjukkan bahwa terdapat pengaruh positif dan signifikan kemampuan metakognisi terhadap hasil belajar matematika siswa. Sehingga, semakin tinggi kemampuan metakognisi yang dimiliki siswa maka semakin tinggi juga hasil belajar matematika yang akan diperoleh. Sebaliknya, semakin rendah kemampuan metakognisi yang dimiliki siswa maka semakin rendah juga hasil belajar matematika yang diperoleh.

Adapun komponen kemampuan metakognisi yang digunakan pada penelitian ini, yaitu (1) Pengetahuan deklaratif, (2) Pengetahuan prosedural, (3) Pengetahuan kondisional, (4) Perencanaan, (5) Strategi manajemen informasi, (6) Pemantauan, (7) Perbaikan (8) Evaluasi. Komponen-komponen tersebut dihubungkan dengan pernyataan-pernyataan yang terdapat pada skala. Hasil belajar matematika yang digunakan dalam penelitian ini yaitu penilaian akhir semester (PAS). Pada pembelajaran matematika tersebut, komponen-komponen dari metakognisi perlu dimiliki oleh siswa dalam mengerjakan tugas-tugas.

Dugaan secara teoritis bahwa kemampuan metakognisi dapat berpengaruh terhadap hasil belajar matematika siswa, karena faktor kemampuan metakognisi ini merupakan salah satu kemampuan yang dibutuhkan siswa dalam menghadapi tugas-tugas atau menyelesaikan masalah dalam pembelajaran matematika. Dalam memecahkan masalah, metakognisi memiliki andil yang penting terlebih saat proses pengaturan aktivitas kognitif yang dapat membuat pekerjaan semakin efektif dan efisien (Mulbar, 2008: 9; Apriyani \& Ibrahim, 2021: 53).

Kemampuan metakognisi mampu mempengaruhi hasil belajar matematika sesuai dengan kajian teoritis bahwa salah satu faktor internal yang mempengaruhi hasil belajar matematika siswa adalah komponen yang terkait kognitif siswa tersebut. Komponen-komponen yang ada pada kemampuan metakognisi berkaitan dengan komponen-komponen yang perlu diakomodasi dalam pembelajaran matematika terutama di saat memecahkan soal matematika (Apriyani \& Ibrahim, 
2021; 49). Dengan demikian data pada penelitian ini mendukung kajian secara teoritis bahwa kemampuan metakognisi berpengaruh positif secara signifikan terhadap hasil belajar matematika siswa.

Komponen-komponen dari kemampuan metakognisi diterapkan dalam pembelajaran matematika, sedangkan penjabaran serta indikator dari setiap komponen-komponen kemampuan metakognisi merupakan kemampuan yang harus dimiliki siswa agar dapat memecahkan masalah saat belajar matematika. Dengan demikian, apabila siswa memiliki kemampuan metakognisi yang tinggi maka hasil belajar matematika siswa cenderung akan tinggi.

Pengujian hipotesis kedua pada penelitian ini, yaitu menguji mengenai pengaruh prokrastinasi akademik terhadap hasil belajar matematika siswa. Hasil analisis mengenai pengaruh prokrastinasi akademik terhadap hasil belajar matematika siswa menunjukkan bahwa adanya pengaruh negatif dan signifikan antara prokrastinasi akademik terhadap hasil belajar matematika siswa. Hal ini sesuai dengan dasar pengambilan keputusan, bahwa jika nilai $t_{\text {hitung }}>t_{\text {tabel }}$ dan nilai sig. $<0,05$ serta koefisien regresi bernilai negatif maka terdapat pengaruh negatif dan signifikan antara prokrastinasi akademik terhadap hasil belajar matematika siswa.

Hasil pengolahan menggunakan software statistik memberikan hasil bahwa nilai $t_{\text {hitung }}$ lebih besar dari $t_{\text {tabel }}$ atau bisa dituliskan dengan $t_{\text {hitung }}(2,339)>$ $t_{\text {tabel }}(1,686)$. Perolehan nilai sig. yaitu pada variabel prokrastinasi akademik terhadap hasil belajar matematika siswa lebih kecil dari 0,05 atau dapat dituliskan dengan sig. $(0.025)<0,05$. Hal ini dapat menunjukkan bahwa data pada penelitian ini mengarahkan pada kesimpulan bahwa prokrastinasi akademik berpengaruh negatif dan signifikan terhadap hasil belajar matematika siswa.

Penelitian ini juga melakukan perhitungan interpretasi model dengan melihat pengaruh prokrastinasi akademik $\left(X_{2}\right)$ terhadap hasil belajar matematika siswa $(Y)$. Dalam perhitungan interpretasi model didapat koefisien regresi dari prokrastinasi akademik $\left(X_{2}\right)$ sebesar -0,505. Dilihat dari koefisien regresi prokrastinasi akademik yang diperoleh tersebut terlihat bahwa koefisien variabel bebas bernilai negatif, artinya variabel prokrastinasi akademik berpengaruh negatif terhadap hasil belajar matematika siswa. Hal ini dapat diartikan bahwa dengan berkurangnya prokrastinasi akademik sebesar -0,505 setiap satuan dapat meningkatkan hasil belajar matematika siswa sebesar 0,505 dengan menganggap bahwa variabel lainnya konstan.

Hasil penelitian ini sesuai dengan hasil yang dilakukan oleh Zuraidah, dkk (2020) dan Arifani \& Purnama (2015) yang menunjukkan bahwa terdapat pengaruh negatif dan signifikan prokrastinasi akademik terhadap hasil belajar matematika siswa. Jadi, semakin tinggi siswa melakukan prokrastinasi akademik maka cenderung semakin rendah hasil belajar matematika yang diperoleh.

Adapun komponen prokrastinasi yang digunakan pada penelitian ini, yaitu: (1) penundaan dalam memulai dan menuntaskan tugas, (2) keterlambatan untuk mengerjakan tugas, (3) selisih waktu yang jauh antara rencana dan kinerja aktual, dan (4) melaksanakan aktivitas yang menyenangkan. Komponen-komponen tersebut dihubungkan dengan pernyataan-pernyataan yang terdapat pada skala. Hasil belajar matematika siswa yang digunakan dalam penelitian ini yaitu penilaian akhir semester (PAS). Pada pembelajaran matematika tersebut, komponen-komponen dari prokrastinasi akademik perlu dihindari oleh siswa 
dalam pembelajaran matematika di sekolah baik dalam belajar maupun mengerjakan tugas-tugas.

Dugaan secara teoritis bahwa prokrastinasi akademik dapat berpengaruh terhadap hasil belajar matematika siswa, karena faktor prokrastinasi akademik ini merupakan salah satu kemampuan yang dapat menghambat terselesaikannya tugas-tugas akademik siswa atau menghambat dalam menyelesaikan masalah dalam pembelajaran matematika. Sebagaimana Solomon dan Rothblum (Setiyowati, 2016: 11) memaparkan bahwa prokrastinasi merupakan bentuk yang mengarah pada menunda-nunda untuk melakukan permulaan mengerjakan tugas, sehingga perilaku ini harus dihindari oleh siswa dalam menyelesaikan tugas-tugas atau soal-soal matematika di sekolah. Siswa yang mempunyai kesulitan untuk menyelesaikan tugas akademik sesuai batas waktu, sering mengalami keterlambatan, atau mempersiapkan suatu tugas dengan sangat berlebihan, seringkali disebabkan oleh menunda-nunda penyelesaian tugas akademik tersebut. Akibat menundanya maka tugas tersebut selesai dengan hasil yang tidak optimal (Ilyas \& Suryadi, 2017: 28). Kebiasaan menunda-nunda tugas tersebut itulah yang akan berpengaruh negatif terhadap hasil belajar matematika.

Temuan penelitian ini sesuai dengan kajian teoritis bahwa salah satu faktor internal yang mempengaruhi hasil belajar matematika siswa adalah komponen yang terkait perilaku siswa tersebut. Apabila terjadi kemunculan komponenkomponen yang ada pada prokrastinasi akademik di saat pembelajaran matematika maka hasil belajar matematika akan terpengaruh negatif. Dengan kata lain, semakin banyak komponen-komponen prokrastinasi muncul saat pembelajaran matematika maka hasil belajar matematika akan semakin rendah.

Pengujian ketiga pada penelitian ini adalah pengujian terhadap pengaruh kemampuan metakognisi dan prokrastinasi akademik secara bersama-sama terhadap hasil belajar matematika siswa. Hasil dari uji $\mathrm{F}$ menunjukkan bahwa kemampuan metakognisi dan prokrastinasi akademik berpengaruh terhadap hasil belajar matematika siswa. Hasil penelitian ini mendukung kajian-kajian teoritis yang ada, yaitu bahwa kemampuan metakognisi dan prokrastinasi akademik merupakan faktor-faktor internal yang dapat mempengaruhi hasil belajar matematika siswa.

Uji koefisien determinasi dilakukan untuk mengestimasi variabel bebas (kemampuan metakognisi dan prokrastinasi akademik) secara bersama-sama mempengaruhi hasil belajar matematika siswa. Hasil perhitungan koefisien determinasi diperoleh nilainya sebesar 34,7\%. Hal ini berarti bahwa hasil belajar matematika $65,3 \%$ dipengaruhi oleh faktor-faktor dari variabel lain yang tidak diteliti.

Temuan penelitian ini, kemampuan metakognisi dan prokrastinasi akademik secara bersama-sama mempengaruhi hasil belajar matematika siswa. Hal ini secara teoritis diduga karena kedua variabel bebas tersebut hadir eksistensinya dalam pembelajaran matematika secara bersama-sama serta saling memberikan kontribusi dalam pembelajaran matematika yang berpengaruh pada hasil belajar matematika. Kemampuan metakognisi yang baik dianggap sebagai faktor yang mendukung untuk memperoleh hasil belajar matematika yang baik. Metakognisi bisa membantu siswa untuk menyadari kemampuannya dalam belajar serta membantu siswa untuk memikirkan strategi-strategi pemecahan masalah yang dihadapinya dalam proses belajar matematika. Sedangkan prokrastinasi 
akademik yang tinggi dianggap sebagai faktor yang menghambat untuk mencapai hasil belajar matematika yang baik. Siswa yang memiliki kesukaran dalam memulai atau menunda-nunda dalam menyelesaikan tugas akademik dengan tepat waktu, besar kemungkinan akan mengalami keterlambatan. Kebiasaan menundanunda tugas tersebut memiliki peluang mempengaruhi terhadap hasil belajar matematika menjadi rendah.

Temuan berdasarkan data penelitian ini sesuai dengan kajian-kajian teori bahwa kemampuan metakognisi dan prokrastinasi akademik bagian dari faktor internal siswa yang berpengaruh pada hasil belajar matematika siswa. Komponenkomponen yang ada pada kemampuan metakognisi dan prokrastinasi akademik sangat mungkin muncul pada pembelajaran matematika. Kemunculan kemampuan metakognitif dalam pembelajaran matematika menjadikan hasil belajar yang baik, sedangkan kemunculan prokrastinasi menjadikan hasil belajar matematikan menjadi tidak baik. Dengan demikian temuan hasil penelitian ini mendukung pada simpulan bahwa ada pengaruh yang signifikan kemampuan metakognisi dan prokrastinasi akademik secara simultan terhadap hasil belajar matematika pada siswa.

\section{SIMPULAN DAN SARAN}

Penelitian ini menyimpulkan kemampuan metakognisi berpengaruh positif secara signifikan terhadap hasil belajar matematika siswa. Kesimpulan lainnya adalah prokrastinasi akademik berpengaruh negatif secara signifikan terhadap hasil belajar matematika siswa. Selain itu, kesimpulan yang dapat ditarik juga adalah kemampuan metakognisi dan prokrastinasi akademik secara bersama-sama berpengaruh signifikan terhadap hasil belajar matematika siswa.

Penelitian ini sudah menunjukkan bahwa kemampuan metakognisi dan prokrastinasi akademik dapat mempengaruhi hasil belajar matematika siswa. Namun demikian, banyak faktor lain yang dapat mempengaruhi hasil belajar matematika siswa. Oleh karena itu untuk penelitian berikutnya diharapkan untuk mengembangkan dan memperluas cakupan-cakupan dan berbeda sehingga hasil penelitiannya dapat dijadikan pijakan dalam upaya meningkatkan hasil belajar matematika yang optimal. Selain itu, penggunaan instrumen yang berbeda agar lebih bervariasi dan mempertegas hasil penelitian khususnya pada variabel hasil belajar matematika. Hasil penelitian ini menyarankan kepada guru untuk menggunakan strategi belajar yang memberikan kesempatan untuk terlatihnya metakognisi siswa, Selain itu, hasil penelitian ini juga menyarankan kepada guru untuk memberikan motivasi belajar pada siswa untuk tidak terjadinya prokrastinasi akademik karena berdampak negatif terhadap hasil belajar matematika siswa.

\section{DAFTAR RUJUKAN}

Agustina, W., \& Noor, F. (2016). Hubungan hasil belajar dan tingkat berpikir kreatif siswa dalam pembelajaran matematika. Math Didactic: Jurnal Pendidikan Matematika, 2(3), 191-200. https://doi.org/10.33654/math.v2i3.49

Apriyani, R., \& Ibrahim. (2021). Students' Metacognitive Process in Mathematical Problem Solving Based on Cognitive Style. Quadratic: Journal of Innovation and Technology in Mathematics and Mathematics 
Education, 1(1), 47-55. https://doi.org/10.14421/quadratic.2021.11-07

Arifani, H., \& Purnami, A. S. (2015). Hubungan Self Efficacy, Motivasi, dan Prokrastinasi Akademik dengan Prestasi Belajar Matematika Siswa Kelas VIII SMP Se-Kecamatan Kraton Yogyakarta. Union: Jurnal Ilmiah Pendidikan Matematika, 3(1), 25-32. http://dx.doi.org/10.30738/.v3i1.273

Arikunto, S. (2010). Prosedur Penelitian Suatu Pendekatan Praktik. Jakarta: Rineka Cipta.

Chairani, Z. (2016). Metakognisi Siswa dalam Pemecahan Masalah Matematika. Yogyakarta: Deepublish.

Faelasofi, R. (2017). Identifikasi Kemampuan Berpikir Kreatif Matematika Pokok Bahasan Peluang. e-DuMath: Jurnal Pendidikan Matematika, 3(2), 155163. https://doi.org/10.26638/je.460.2064

Fajriani, \& Nurdahniar. (2016). Pengaruh Metakognisi terhadap Hasil Belajar Matematika Siswa Kelas X SMA Negeri Se Kabupaten Bulukumba. Prosiding Seminar Nasional 2(1), 285-290. https://www.google.com/url?sa=t\&rct=j\&q=\&esrc=s\&source=web\&cd=\&c ad=rja\&uact=8\&ved=2ahUKEwiVu9G7zPDwAhUB4HMBHS8fDkQQFjA AegQIAxAD\&url=https\%3A\%2F\%2Fjournal.uncp.ac.id\%2Findex.php\%2F proceding\%2Farticle\%2Fview\%2F423\%2F364\&usg=AOvVaw08Yto4Ulx _ 226Rq9UNa5IR

Gani, A. (2015). Pengaruh Model Pembelajaran dan Persepsi Tentang Matematika Terhadap Minat dan Hasil Belajar Matematika Siswa SMP Negeri Di Kecamatan Salomekko Kabupaten Bone. Daya Matematis: Jurnal Inovasi Pendidikan Matematika, 3(3), 337-343. https://doi.org/10.26858/jds.v3i3.1700

Harahap, D. H., \& Syarifah, R. (2015). Studi Kasus Kesulitan Belajar Matematika pada Remaja. Jurnal Psikologi, 11(1), 20-30. https://ejournal.up45.ac.id/index.php/psikologi/article/view/109/105

Hasibuan, A. A. (2018). Kontribusi Lingkungan Belajar dan Proses Pembelajaran terhadap Prestasi Belajar Siswa Di Sekolah. Tarbiyah, 25(2), 1-20. https://doi.org/10.30829/tar.v25i2.365

Ibrahim. (2019). Pendekatan Ramah, Terbuka dan Komunikatif pada Pembelajaran Matematika di SMP. Jurnal Mercumatika: Jurnal Penelitian Matematika dan Pendidikan Matematika, 4(1), 39-46. https://dx.doi.org/10.26486/jm.v4i1.1160

Ilyas, M., \& Suryadi, S. (2017). Perilaku Prokrastinasi Akademik Siswa di SMA Islam Terpadu (IT) Boarding School Abu Bakar Yogyakarta. An-Nida', 41(1), 71-82. http://dx.doi.org/10.24014/an-nida.v41i1.4638

Lestari, K. E., \& Yudhanegara, M. R. (2015). Penelitian Pendidikan Matematika. Bandung: Refika Aditama.

Mulbar, U. (2008). Metakognisi Siswa dalam Menyelesaikan Masalah Matematika. Prosiding Seminal Nasional Pendidikan Di IAIN Sunan Ampel Surabaya.

Munawaroh, M. L., Alhadi, S., \& Saputra, W. N. (2017). Tingkat Prokrastinasi Akademik Siswa Sekolah Menengah Pertama Muhammadiyah 9 Yogyakarta. Jurnal Kajian Bimbingan dan Konseling, 2(1), 26-31. http://dx.doi.org/10.17977/um001v2i12017p026

Muyana, S. (2018). Prokrastinasi Akademik Dikalangan Mahasiswa Program 
Studi Bimbingan dan Konseling. Counsellia: Jurnal Bimbingan dan Konseling, 8(1), 45-52. http://doi.org/10.25273/counsellia.v8i1.1868

Nitami, M., Daharnis, \& Yusri. (2015). Hubungan Motivasi Belajar dengan Prokrastinasi Akademik Siswa. Konselor, 4(1), 1-12. https://doi.org/10.24036/02015416449-0-00

Nurmalasari, L. R., Winarso, W., \& Nurhayati, E. (2015). Pengaruh Kemampuan Metakognisi terhadap Hasil Belajar Matematika di SMP Negeri 2 Leuwimunding Kabupaten Majalengka. Nusantara of Research, 2(2), 133147. https://ojs.unpkediri.ac.id/index.php/efektor/article/view/171

Paristu, B. P. (2020). Hubungan Pengetahuan Metakognisi dengan Kesadaran Metakognisi pada Siswa. Skripsi tidak diterbitkan. Jakarta: Fakultas Ilmu Tarbiyah dan Keguruan UIN Syarif Hidayatullah.

Puspendik. (2019). Pendidikan di Indonesia: Belajar dari Hasil PISA 2018. Jakarta: Balitbang Kemendikbud RI.

Puspendik. (2020). Laporan Hasil Asesmen Kompetensi Siswa Indonesia. Badan Penelitian dan Pengembangan Kemendikbud Republik Indonesia. https://aksi.puspendik.kemdikbud.go.id/laporan/

Siagian, M. D. (2016). Kemampuan Koneksi Matematik dalam Pembelajaran Matematika. MES: Journal of Mathematics Education and Science, 2(1), 58-67. https://doi.org/10.30743/mes.v2i1.117

Siagian, R. E. F. (2015). Pengaruh Minat dan Kebiasaan Belajar Siswa Terhadap Prestasi Belajar Matematika. Formatif: Jurnal Ilmiah Pendidikan MIPA, 2(2), 122-131. http://dx.doi.org/10.30998/formatif.v2i2.93

Suardi, M. (2013). Pengaruh Motivasi Belajar dan Kecerdasan Emosional terhadap Kesadaran Metakognisi dan Kaitannya dengan Hasil Belajar Matematika Siswa Kelas XI IPA SMA Negeri di Kabupaten Sinjai. Tesis tidak diterbitkan. Jakarta: Program Pascasarjana Universitas Terbuka.

Sugiyono. (2015). Statistika untuk Penelitian. Bandung: Alfabeta.

Sukardi. (2011). Metodologi Penelitian Pendidikan: Kompetensi dan Praktiknya. Jakarta: Bumi Aksara.

Sulistiani, E., \& Masrukan, M. (2017). Pentingnya Berpikir Kritis dalam Pembelajaran Matematika untuk Menghadapi Tantangan MEA. PRISMA, Prosiding Seminar Nasional Matematika, 605-612. https://journal.unnes.ac.id/sju/index.php/prisma/article/view/21554

Supriatna, E., \& Alawiyah, T. (2019). Studi Keterampilan Metakognitif pada Siswa Sekolah Menengah Atas (SMAN) 1 Margaasih Kabupaten Bandung. Irsyad: Jurnal Bimbingan, Penyuluhan, Konseling, dan Psikoterapi Islam, 7(4), 471-480. https://doi.org/10.15575/irsyad.v7i4.1772

Syamarro, N. (2015). Pengaruh Motivasi dan Persepsi Siswa pada Matematika Terhadap Prestasi Belajar Matematika Siswa Kelas VIII di MTs AlHiyadayah Dukupuntang Kabupaten Cirebon (Pokok Bahasan Kubus dan Balok). Skripsi tidak diterbitkan. Cirebon: Fakultas Ilmu Tarbiyah dan Keguruan IAIN Syekh Nurjati.

UU RI No. 20 Tahun 2003 Tentang Sistem Pendidikan Nasional. (2003). Jakarta: Armas Duta Jaya.

UUD RI Tahun 1945 BAB XIII Tentang Pendidikan dan Kebudayaan. (2002). Jakarta.

Yusmin, E. (2017). Kesulitan Belajar Siswa pada Pelajaran Matematika 
(Rangkuman dengan Pendekatan Meta-Ethnography). Jurnal Visi Ilmu Pendidikan, 9(1), 21-36. https://dx.doi.org/10.26418/jvip.v9i1.24806

Zuraidah, D., Sari, T. H. N. I., \& Yuniarti, S. (2020). Pengaruh Kecemasan Matematika dan Prokrastinasi Akademik Siswa terhadap Hasil Belajar Matematika Siswa Kelas VIII SMP Negeri 7 Balikpapan. Inspiramatika: Jurnal Inovasi Pendidikan dan Pembelajaran Matematika, 6(1), 1-7. https://doi.org/10.52166/inspiramatika.v6i1.1922 